\title{
KAJIAN BIBLIKA 1KORINTUS 15: 1-11 BAGI PEMAHAMAN IMAN KRISTEN TENTANG KEBANGKITAN YESUS KRISTUS
}

\author{
Moses Wibowo; Tony Salurante \\ Sekolah Tinggi Teologi Injili Arastamar Jakarta \\ mwibowo@sttsetia.ac.id,tony.salurante@sttsetia.ac.id
}

\begin{abstract}
The doctrine of the resurrection of Christ is one of the foundations in Christianity. But the foundation of this faith continues to be challenged and attacked. One of the attacks came from Rudolf Bultmann, who believed that the resurrection of Jesus Christ was only a spiritual awakening and not even an objective historical reality. In the Indonesian context there is a tradition called "Rambu Solo." This tradition believes that the slaughter of a buffalo will contribute to keeping the spirits of the dead safe. The doctrine of the resurrection in Corinth was due to a problem of misunderstanding. These situations will continue to occur in various places. Therefore, this article examines Paul's teachings in 1 Corinthians 15, especially verses 1-11 as an attempt to answer the teachings and practices of life that do not understand the work of the resurrection of Jesus Christ. The method used is biblical exegesis of 1Corinthians 15: 1-11. It is through exegesis that the resurrection of Jesus Christ is an objective historical reality. That He did rise from physical death. The exegesis significance of 1 Corinthians 15:1-11 for Bultmann's teachings and the tradition of "Rambu Solo" indicate that the two are not biblical.
\end{abstract}

Keywords: $\quad$ Study, Biblical, Understanding of Faith, The Resurrection.

\begin{abstract}
Abstrak: $\quad$ Doktrin kebangkitan Kristus merupakan salah satu fondasi iman orang percaya. Akan tetapi fondasi iman ini terus mendapat tantangan dan serangan. Salah satunya adalah Rudolf Bultmann yang menyakini bahwa kebangkitan Yesus Kristus hanyalah kebangkitan spiritual dan bahkan bukan realitas-historis obejektif. Di dalam konteks Indonesia terdapat tradisi “Rambu Solo." Tradisi ini mempercayai bahwa dengan cara memotong kerbau akan berkontribusi menjaga roh orang mati sampai ke tempat aman. Ajaran tentang kebangkitan dalam 1Korintus ada karena masalah pemahaman yang keliru. Situasi ini bisa terus terjadi diberbagai tempat. Oleh karena itu artikel ini akan meneliti ajaran Paulus dalam 1 Korintus 15, khususnya ayat 1-11 sebagai usaha menjawab ajaran dan praktik hidup yang kurang memahami akan karya kebangkitan Yesus Kristus. Metode yang dipakai adalah eksegesis biblikal terhadap 1 Korintus 15:1-11. Melalui eksegesis dihasilkan bahwa kebangkitan Yesus Kristus adalah suatu realitas historis objektif. Bahwa Ia bangkit dari kematian fisik. Signifikansi eksegesis 1Korintus 15: 1-11 bagi ajaran Bultmann dan tradisi "Rambu Solo" menunjukkan bahwa keduanya tidak biblikal.
\end{abstract}

Kata kunci: Kajian, Biblika, Pemahaman Iman, Kebangkitan.

\section{PENDAHULUAN}

Kebangkitan Yesus Kristus adalah bagian mujizat yang terjadi secara

historis. Namun demikian tidak mudah untuk diterima oleh kebanyakan manusia 
yang hidup di era ini. ${ }^{1} \quad$ Kebangkitan Yesus dianggap tidak rasional dan tidak sesuai dengan hukum ilmu pengetahuan. ${ }^{2}$ Ajaran yang fundamental menjadi ajaran sentral dalam iman Kristen. Kebangkitan Yesus Kristus bukan hanya menjadi bukti dari keilahian-Nya, namun juga menggenapi dan memvalidasi nubuatan Perjanjian Lama yang dituturkan para nabi tentang penderitaan dan kebangkitan Yesus (lih. Kis. 17: 2-3). Paulus menyatakan; “jika Kristus tidak dibangkitkan, maka sia-sialah kepercayaan kamu dan kamu masih hidup dalam dosamu. Demikianlah binasa juga orang-orang yang mati dalam Kristus” (1Kor. 15: 17-18).

Secara retrospektif Bultmann pernah mengatakan seperti dikutip Geisler bahwa kebangkitan Yesus yang dituturkan dalam Perjanjian Baru adalah mitologi belaka. Yesus Kristus tidak bangkit dari kubur tetapi hanya dalam hati atau iman para murid semata. ${ }^{3}$ Pandangan ini telah banyak mempengaruhi termasuk orang percaya pada periode Bultmann hidup bahkan juga sampai sekarang; literatur dan film yang menyajikan bahwa makam Yesus telah ditemukan dan Yesus tidak bangkit secara fisik. ${ }^{4}$ Kondisi ini menjadi ancaman yang membahayakan bagi kekohan iman orang percaya apabila padangan di atas diterima.

Artikel ini akan mengimplikasikan kepada salah satu contoh dalam konteks budaya di Indonesia yaitu tradisi suku Toraja: Rambu Solo. Tradisi ini adalah kepercayaan nenek moyang orang Toraja mengenai kebangkitan orang mati dapat menjadi riset yang menarik untuk memaknai apa artinya percaya akan

\footnotetext{
${ }^{1}$ David J. Norman, "Doubt and the Resurrection of Jesus," Theological Studies 69, no. 4 (2008): 786-811, https://doi.org/10.1177/004056390806900402.

2 Joseph A. Bracken, "Incarnation, panentheism, and bodily resurrection: A systems-oriented approach," Theological Studies 77, no. 1 (2016): 32-47, https://doi.org/10.1177/0040563915619977.

${ }^{3}$ Norman L. Geisler, Miracles and the Modern Mind (Grand Rapids: Bakerbook House, 1991)., 70.

${ }^{4}$ Darrell L. Bock dan Daniel B. Wallace, Mendongkel Yesus dari Tahta-Nya:Upaya Mutakir untuk Menjungkir-Balikkan Iman Gereja Mengenai Yesus Kristus (Jakarta: Gramedia, 2009).
} 
kebangkitan di dunia modern di tengah kebudayaan lokal. Orang Toraja masih memelihara suatu ritual yang akan membawa roh orang mati ke suatu tempat (Puya). Sarana yang digunakan untuk “mengamankan" arwah melalui mengorbankan beberapa ekor kerbau. Semakin banyak kerbau yang dipotong semakin lancar perjalanan roh seseorang yang telah meninggal ke peristirahatan terakhir.

Tujuan dari artikel adalah menjawab pertanyaan tentang bagaimanakah ajaran tentang kebangkitan Yesus Kristus dalam 1Korintus 15: 1-11 dapat berkontribusi bagi pertubuhan iman orang percaya di masa kini dalam relasi dengan pandangan Bultmann dan ritual "Rambu Solo" di Toraja? Untuk menjawab pertanyaan tersebut maka menghadirkan beberapa sub pertanyaan. Pertama, bagaimana ajaran tentang kebangkitan Yesus Kristus menurut 1 Korintus ketika dinterpretasikan? Kedua, bagaimana hasil interpretasi tentang kebangkitan Yesus Kristus berimplikasi terhadap padangan Bultmann dan tradisi suku Toraja tentang ritual "Rambu Solo" serta sikap hidup orang percaya?. Melalui riset terhadap 1Korintus 15: 1-11 diharapkan akan membawa signifikansi teologis dan praktis dalam usaha menjawab tantangan dari pandangan Bultmann. Kemudian juga mencoba mengkontekstualisasikan dengan situasi dari salah satu kebudayaan di Indonesia yaitu tradisi "Rambu Solo" dari tanah Toraja-Sulawesi Selatan.

\section{METODE}

Metodologi yang digunakan adalah eksegesis biblikal dengan menggunakan pola studi eksegetikal yang membaginya dalam lima bagian utama; introduksi, konteks, makna, signifikansi dan kesimpulan. Dalam pelaksanaannya 
bagian 1Korintus 15: 1-11 akan didekati dengan metode eksegesis jenis struktrur tafsiran. Pendekatan ini bergerak dari bagian dari ayat ke ayat dengan menyajikan wawasan eksegesis yang relevan pada suatu perikop tertentu dengan mendiskusikan beberapa elemen; sejarah, kultur, redaksional, grammatikal, lesikal dan beberapa tipe dari suatu penelitian eksegesis. ${ }^{5}$ Menurut Fee, eksegesis adalah menemukan dan memahami pesan dari sang penulis teks. ${ }^{6}$ Usaha ini adalah bagian dari menginvestigasi teks dalam konteks historisnya. ${ }^{7}$ Kebangkitan Yesus Kristus adalah suatu realitas historis objektif dan menjadi fondasi iman orang percaya tentang kebangkitan tubuh.

\section{HASIL}

Kebangkitan Yesus Kristus adalah dasar penting dalam kehidupan Kristen. Namun pemikiran Rudolf Bultmann menolak tentang realitas kebangkitan Yesus Kristus adalah suatu ancaman dan suatu bentuk penyankalan Iman Kristen. Ajaran tentang kebangkitan Yesus Kristus adalah sebuah jawaban yang mentransformasi budaya "Rambu Solo" yang dilakukan di suku Toraja, Sulawesi Selatan. Penjelasan ajaran kebangkitan Yesus Kristus membuka kesempatan bagi pemberitaan Injil kepada suku Toraja. Hal ini mentransformasi pemahaman tentang kebangkitan Yesus Kristus yang dikontekstualiasikan. Penulis meneliti konsep upacara kematian "Rambu Solo" tidak alkitabiah karena konsep tersebut memahami bahwa roh dari hewan yang dikorbankan menjadi sarana untuk

\footnotetext{
${ }^{5}$ Kevin Gary Smith, Writing and Risearch: A Guide for Theological Student (UK: Langham Global Library, 2016). 131-137.

${ }^{6}$ Gordon D. Fee, Exegese van het Nieuwe Testament: een praktische handleiding (Zoetermeer: Boekencentrum, 2007). 7.

${ }^{7}$ Stanley E. Porter dan Kent D. Clarke, "What Is Exegesis? An Analysis of Various Definitions," dalam Handbook to the exegesis of the New Testament, ed. oleh Stanley E. Porter (Leiden: BRILL, 1997), 321.
} 
membawa jiwa orang yang telah mati untuk menuju kepada peristirahatan terakhir. Penelitian ini menghasilkan suatu terobosan pemikiran baru dalam mentransformasi budaya sehingga sesuai dengan prinsip Alkitab yaitu menjadikan Yesus Kristus dan karya-Nya sebagai fondasi iman dan tindakan orang percaya.

\section{PEMBAHASAN}

Pada bagian ini akan mengulas tentang bagaimana latar belakang dari ajaran tentang kebangkitan Yesus Kristus yang dituturkan oleh rasul Paulus kepada jemaat di Korintus. Ada dua pokok utama yang akan dibahas yaitu analisis teks dan konteks 1 Korintus 15:1-11.

\section{Analisis Teks 1 Korintus 15:1-11}

Berkaitan dengan menentukan kesatuan terkecil ada berbagai pendapat yang bervariasi. ${ }^{8}$ Pendapat yang menjadikan ayat 1-11 sebagai kesatuan terkecil didasarkan bahwa adanya kesamaan oknum dan pokok pembahasan (Paulus dan mereka dan kalian ayat 11, kebangkitan Kristus) dari pada memisahkannya. Kemudian ayat 12 adalah bagian yang baru. Karena ayat 12 memulai dengan pokok yang baru yaitu "adanya pertanyaan bahwa tidak ada kebangkitan orang

\footnotetext{
${ }^{8}$ Ciampa dan Rosner berpandangan bahwa 1 Korintus 15 dapat dibagi dalam tujuh bagian utama dan pasal 15: 1-11 dan salah satunya adalah tentang proklamasi kebangkitan Yesus Kristus. Lihat: Roy E. Ciampa dan Brian S. Rosner, The First Letter to the Corinthians (England: Apollos, 2010). Bray membagi 1 Korintus 15 menjadi sembilan bagian dan pasal 15:1-11 telah dibagi menjadi dua bagian. Bahwa ayat 1-7 berisi tentang pengakuan iman dan ayat 8-11 berisi tentang pengakuan Paulus secara spesifik. Lihat: Gerald. Bray, 1-2 Corinthians. Ancient Christian Commentary on Scripture New Testament VII, ed. oleh Gerald . Bray (Downers Grove: InterVarsity, 1999)., 148-84. Menurut Fee \& Douglas, bahwa pasal 15:1-11 tidak dapat dipisahkan dari konteks pembicaraan Paulus dari pasal 12-14. Pada bagian ini Paulus sedang menjawab tentang "the abuse of speaking in tongues." Lihat: Gordon D. Fee dan Douglas. Stuart, How to Read the Bible Book By Book: a Guided Tour (Grand Rapids: Zondervan, 2002)., 330.
} 
mati." Untuk mengetahui secara persis mengapa bagian ini muncul adalah tidak mudah, tetapi isu dalam konteks ini jelas yaitu adanya pertanyaan pada ayat $12 .{ }^{9}$

Fee juga berpendapat bahwa pasal 15:1-11 merupakan respons Paulus karena adanya penyangkalan kebangkitan tubuh (ayat 12) dan "apparently ridiculing the idea of a raised body" (ayat 33). ${ }^{10}$ Pasal 15:1-11 adalah kesatuan terkecil dan merupakan bagian dari keseluruhan pasal 15. Bagian ini berfungsi untuk mengoreksi ketersesatan yang fatal dari jemaat di Korintus. ${ }^{11}$ Bahwa Paulus sedang menegasi pandangan bahwa tidak ada kebangkitan orang mati (1 Kor. 15: 16, 29, 32).

Orisinal manuskrip kitab Perjanjian Baru sudah tidak ada lagi. Walaupun demikian komunitas Kristen mempunyai salinan dari yang orisinal tersebut. Pendapat Green dalam relasi ketiadaan orisinal teks:

We need the discipline of textual criticism because we do do not have orisinal manuscripts of any of the books of NT. What we have are copies that were made musch later than orisinals, in most instances many centuries later. These later copies were not themselves made from the autographs; they were instead made from copies of copies of copies of the autographs. $^{12}$

Kondisi ini menghadirkan problem, karena ada perbedaan dari berbagai salinan yang ada. Studi teks diperlukan sebagai usaha mendapatkan teks yang berkualitas dan sesuai dengan orisinalnya. ${ }^{13}$ Teks Yunani 1 Korintus adalah teks berkualitas karena menurut Kistemaker; "The Greek text of 1 Corinthians has the

\footnotetext{
${ }^{9}$ Gordon D. Fee, The First Epistle to the Corinthians (Grand Rapids: Eerdmans, 2014)., 713.

${ }^{10}$ Fee dan Stuart, How to Read the Bible Book By Book: a Guided Tour.

${ }^{11}$ Ben Witherington III, Conflict \& Community in Corinth: A Sosio-Rhetorical Commentary on 1 and 2 Corinthians (Grand Rapids: Eerdmans, 1995)., 291.

12 Bart D. Ehrman, "Textual Criticism of the New Testament," dalam Hearing the New Testament:Srategies for Interpretation, ed. oleh Joel B. Green (Grand Rapids: Eerdmans, 2010).

${ }^{13}$ Ehrman.
} 
support of papyrus document $\left(\mathrm{P}^{46}\right)$ and mayor witnesses (both unicials and minuscules)." 14

Dalam studi teks hanya memilih bagian teks yang relevan dan berdampak

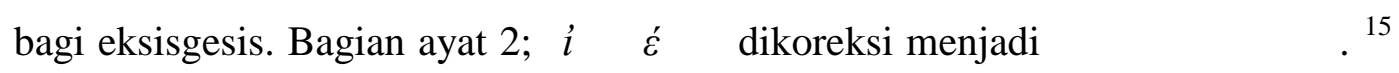

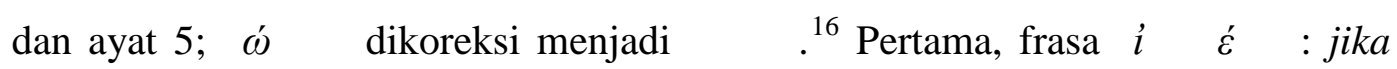
kalian memengang teguh telah dikoreksi menjadi "kalian harus memegang teguh." Hal ini terjadi diduga karena adanya usaha untuk menyederhanakan konstruksi kalimat sehingga lebih mudah dipahami. ${ }^{17}$

Archibald dan Plummer menyatakan bahwa penerima koreksian ini menduga bahwa ini adalah tafsiran terhadap teks orisinalnya. ${ }^{18}$ Thiselton berpendapat;“The change is understandable, so even if Zuntz were correct in arguing that one version of $\mathrm{P}^{46}$ also has the secondary reading, this would not alter

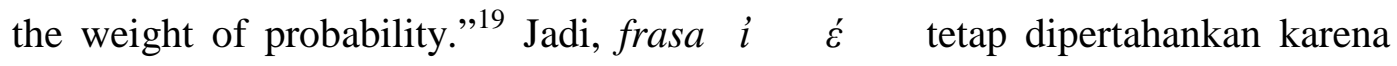
didukung oleh teks-teks yang lebih tua dan tidak mempengaruhi maksud Paulus. ${ }^{20}$ Bahwa Paulus tidak sedang memberikan perintah baru tetapi sedang mengingatkan jemaat di Korintus.

Kedua, ayat 5 teks otentik $\delta \omega ́ \delta \varepsilon \kappa \alpha$ diduga telah dikoreksi menjadi ' $\varepsilon v \delta \varepsilon \kappa \alpha$. Alasannya, karena setelah Yudas Iskariot tiada maka secara spekulatif kedua belas

${ }^{14}$ Simon J. Kistemaker, First Epistle to the Corinthians (Grand Rapids: Baker Academic, 1993)., 25-26. Teks yang dipakai dalam artikel ini adalah teks Yunani menurut Nesle-Aland edisi 28.

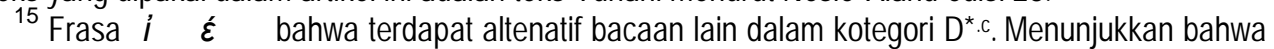
teks tipe $\mathrm{D}$ adalah western teks telah melakukan koreksi terhadap orisinal bacaan dari manuskrip menjadi

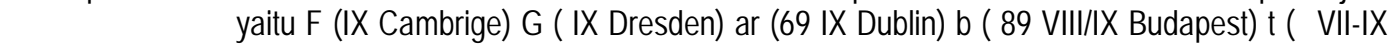
Liber Comicus), vgms (Vulgata individual manuscript); Ambst (Ambrosiaster).

${ }^{16}$ Kata "$\delta \omega \dot{\delta \varepsilon \kappa \alpha " ~ t e r m a s u k ~ k a t e g o r i ~} D^{*}$. Terdapat bacaaan yang lain pada teks tipe $D$ dengan mengoreksi menjadi $\varepsilon v \delta \varepsilon \kappa \alpha$ yaitu (Western text): $\mathrm{F} \mathrm{G}$ latt (The entire Latin Tradition) syhmg (Marginal reding of the Harklensis).

${ }^{17}$ Robertson Archibald dan Alferd Plummer, ed., A Critical and Exegetical on the first Epistle of ST Paul to the Corinthians. International Critical Commentary (Edinburgh: T. \& T. Clark, 1914)., 332.

${ }^{18}$ Fee, The First Epistle to the Corinthians., 789. 1185.

${ }^{19}$ Antony C. Thiselton, The First Epistle to the Corinthians (Grand Rapids: Eerdmans, 2000).,

${ }^{20}$ Ehrman, "Textual Criticism of the New Testament." 
yang di maksud di dalamnya adalah Matias. ${ }^{21}$ Metzger berpendapat "Instead of recognizing that $\delta \omega \delta \delta \varepsilon \kappa \alpha$ is used here as an official designation.” Jadi, mengoreksi menjadi $\varepsilon v \delta \varepsilon \kappa \alpha$ adalah "pedantic corretion.,"22 Héring sependapat, bahwa sebutan "kedua belas" adalah "formal titel for the corporate apostolic witness of those who had also followed Jesus during his earthly life, and who therefore underlined the continuty of witness to the One who has bott crucified and raised." ${ }^{23}$ Jadi, kata " $\delta \omega ́ \delta \varepsilon \kappa \alpha: ~ k e d u a$ belas" tetap dipertahankan dan berfungsi sebagai sebutan umum bagi para rasul.

\section{Analisis Konteks 1 Korintus 15:1-11}

Secara konteks genre 1 Korintus adalah sebuah surat. ${ }^{24}$ Sebagai sebuah surat 1 Korintus berisi tentang teologi dan menawarkan tentang instruksi etik. ${ }^{25} 1$ Korintus ditulis oleh rasul Paulus sekitar tahun 55-56. ${ }^{26}$ Paulus menulis ketika ia berada di kota Efesus dalam masa akhir perjalanan misinya yang kedua sebagai wujud penggembalaan kepada jemaat di Korintus. ${ }^{27}$

Tujuan Paulus utama menulis 1 Korintus adalah memberikan jawaban kongkrit atas masalah kehidupan praktis jemaat di Korintus dalam relasi iman mereka kepada Yesus Kristus. ${ }^{28}$

${ }^{21}$ Thiselton, The First Epistle to the Corinthians., 1205.

22 Bruce M. Metzger, A Textual Commentary on The Greek New Testament (New York: American Bible Society, 2002)., 500.

${ }^{23}$ Thiselton, The First Epistle to the Corinthians., 1205.

24 James L. Bailey, "Genre Analysis," dalam Hearing the New Testament:Srategies for Interpretation (Grand Rapids: Eerdmans, t.t.).

25 William W. Klein, Craig L. Blomberg, dan Jr. Hubbard, Robert L., Introduction to Biblical Interpretation (Dallas: Thomas Nelson, 2004)., 426-227.

${ }^{26}$ Archibald dan Plummer, A Critical and Exegetical on the first Epistle of ST Paul to the Corinthians. International Critical Commentary., xxxiii. Lihat juga; D.A. Carson dan Moo Douglas J., An Introduction To The New Testament (Grand Rapids: Zondervan, 1992)., 448. Lihat juga: R. Dean Aderson, 1 Korintiërs: Orde Op Zaken in Een Jonge Stadskerk (Utrecht: KOK, 2012), 22-23; Jakob van Bruggen, Paulus: Pionier voor de Messias van Israël (Kampen: KOK, 2001), 275.

${ }^{27}$ Kistemaker, First Epistle to the Corinthians., 24.

${ }^{28}$ Kistemaker., 24. 
Korintus menjadi salah satu pusat kota yang maju di kerajaan Romawi. Penduduk di Korintus memiliki kepercayaan bervariasi; Pertama, Helenisme. Budaya Yunani telah mempengaruhi secara luas diberbagai bidang di kota Korintus. Carson dan Moo menjelaskan bahwa:

Romans dominated the scene with their laws, culture, and religion much of empire had been thoroughly Helenized, however, so not only was the lingua franca Greek but doubtless many ties - religious, philosophical and cultural." 29

Paganisme Yunani-Romawi cenderung menekankan tentang kekuntungan pada saat mereka masih hidup seperti sehat dan aman. ${ }^{30}($

Kedua. Yudaisme. Bahwa terdapat ajaran tentang kebangkitan tubuh;

Most scholars agree that the doctrine of bodily resurrection is a fairly late development within the writings of Judaisme. The first unambiguous declarations in the OT of resurrection from the dead accur in Daniel 12:2 (...) although there are antecendents of it in the miracles of resurrection performed through Elijah en Elisha (1 and 2 Kings). ${ }^{31}$

Dalam konteks kebangkitan telah ada beberapa kepercayaan seperti Yahudi maupun Yunani sekalipun berbeda dengan apa yang diajarkan oleh Paulus. Penduduk Korintus menyembah banyak dewa (1 Kor.8:5). Mereka juga mengkultuskan Kaisar. Kondisi inilah yang menjadi sumber masalah antara Paulus dan anggota-anggota jemaat yang kaya (1 Kor. 8:1-11:1 band. 1 Kor. 2:2). Oleh karena itu orang Yunani telah menganggap bahwa kepercayaan kepada Sang penyelamat yang disalibkan adalah suatu kebodohon besar. ${ }^{32}$

\footnotetext{
${ }^{29}$ Carson dan Douglas J., An Introduction To The New Testament.

${ }^{30}$ Witherington III, Conflict \& Community in Corinth: A Sosio-Rhetorical Commentary on 1 and 2 Corinthians., 293.

${ }^{31}$ Gerald F. Hawthorne, Ralph P. Martin, dan Daniel G. Reid, ed., Dictionary of Paul and His Letters (Downers Grove: IVP Academic, 1993)., 806.

${ }^{32}$ David E. Garland, 1 Corinthians (Grand Rapids: Baker Academic, 2003)., 9-12.
} 
Paganisme era itu mengajarkan magic di kuburan yaitu memanggilan roh nenek moyang yang dianggap genius. Mereka juga mempraktikan bantisan orang mati (1 Kor. 15:29) dan kremasi. Praktik-praktik ini adalah bagian dari religiusitas mereka. ${ }^{33}$ Marshall menyimpulkan bahwa ada kemungkinan terjadi kebingungan atau pemahaman yang kurang jelas akan keyakinannya terhadap Injil yang telah disampaikan kepada mereka. ${ }^{34}$ Mereka dipengaruhi oleh dualisme Helenistis dengan menekankan kepada hal "spiritual," dan menggap hal jasmani tidak penting dan menyangkal kebangkitan tubuh. ${ }^{35}$ Kondisi telah membawa berbagai masalah dalam jemaat di Korintus, baik dalam masalah teologi dan masalah etik di dalam komunitas Kristen yang juga berakar dari Yudaisme pada waktu itu.

\section{Interpretasi 1 Korintus 15:1-11}

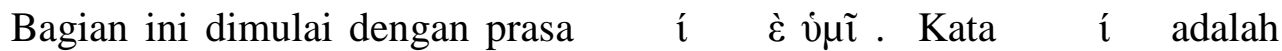
kata yang tidak mudah untuk diterjemahkan. ${ }^{36}$ Ada beberapa perbedaan terjemahan, misalnya; LAI: aku mau mengingatkan kamu; ILT: aku memberitahukan. Lexicon: aku membuat kamu mengingat; ${ }^{37}$ NIV: I remind you dan KJV: I declare unto you. Robertson en Plummer memilih menerjemahkan

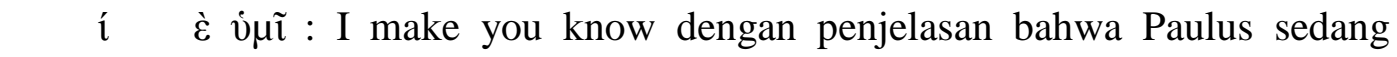
mengajar lagi, bahwa "He has to begin again and teach them an elementary fact, which they had already accepted." ${ }^{38}$ Hal ini terjadi karena mereka menolak

\footnotetext{
${ }^{33}$ Witherington III, Conflict \& Community in Corinth: A Sosio-Rhetorical Commentary on 1 and 2 Corinthians., 293.

${ }^{34}$ Kistemaker, First Epistle to the Corinthians., 37.

${ }^{35}$ Lihat:1 Kor. 6:13; 15:12; band. 5:12;6:12-20; 7:1-6.

${ }^{36}$ Thiselton, The First Epistle to the Corinthians., 1183.

37 Johan Murre, Lexicon: Nieuwe Testament (The Nederlands: Skandalon, 2009)., 186.

${ }^{38}$ Archibald dan Plummer, A Critical and Exegetical on the first Epistle of ST Paul to the Corinthians. International Critical Commentary.
} 
pandangan yang menerjemahkan $\gamma v \omega \rho i \zeta \zeta \omega-\alpha v \alpha v \eta \sigma \kappa \omega .{ }^{39}$ Tetapi pandangan ini ditolak oleh karena dalam konteks ini jemaat di Korintus sudah mengetahui apa yang diajarkan oleh Paulus. ${ }^{40}$ Dalam menerjamahkan $v \omega \rho \hat{\zeta} \zeta \omega$ perlu

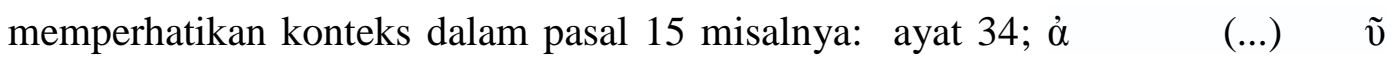

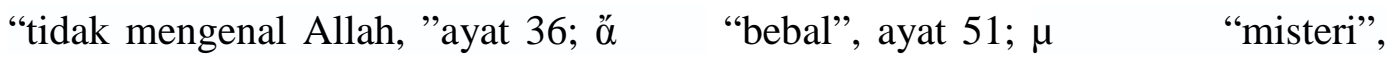

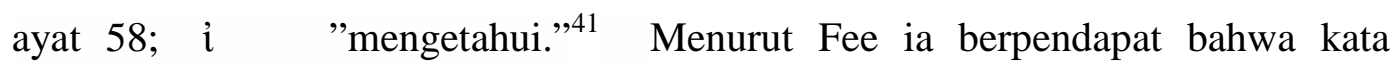

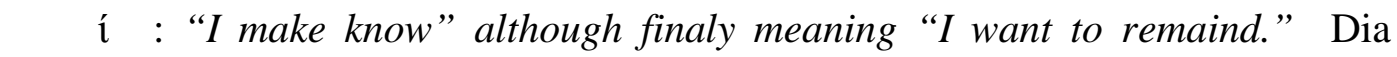
menjelaskan bahwa kata $\gamma \nu \omega \rho i ́ \zeta \omega$ adalah suatu ironi dari 1 Kor. 14:38; عỉ $\delta \dot{~} \tau 1$

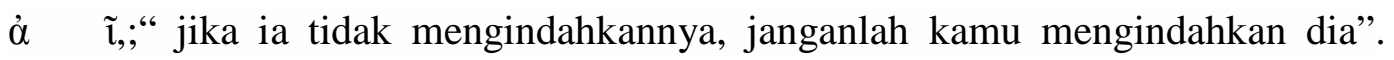
Paulus ingin memberi tahu kepada mereka tentang sesuatu yang dulu mereka telah tahu akan tetapi mereka telah menjadi lupa atau tidak megindahkannya lagi. ${ }^{42}$ Alasan yang dituturkan oleh Fee lebih lebih logis. Secara literal $\gamma v \omega \rho i ́ \zeta \omega ~ \delta \grave{\varepsilon} \dot{v}$ iv diterjemahkan "aku memberitahukan kamu." Akan tetapi setelah dilakukan

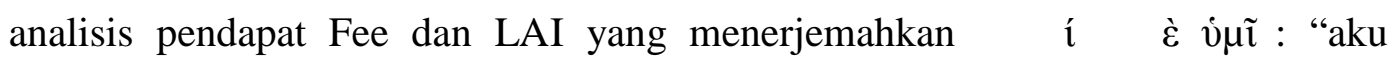
mengingatkan kamu." lebih logis. Walaupun lebih merupakan tafsiran dari pada terjemahan. Di sini Paulus menggunakan frasa yang sama seperti dalam 1 Korintus 12:3 (Band. 2 Kor. 8:1; Gal. 1:1) yang secara literal berarti, "aku memberitahukan.” Tetapi ia tidak mengatakan sesuatu yang baru kepada pembaca melainkan apa yang pernah mereka terima dari padanya dan para pekabar Injil lainnya (lihat ayat 11). Paulus hendak mengatakan "aku ingin kalian yakin benar akan sesuatu, yakni kepada Injil yang aku beritakan kepadamu.” Jadi, Paulus sendang mengingatkan jemaat di Korintus. (Lih. 14: 37-38; 15:33-34).

\footnotetext{
${ }^{39}$ Archibald and Plummer, A Critical and Exegetical on the First Epistle of ST Paul to the Corinthians, 331

${ }^{40}$ Thiselton, The First Epistle to the Corinthians., 1183.

${ }^{41}$ Thiselton., 1183.

${ }^{42}$ Fee, The First Epistle to the Corinthians., 799.
} 
Paulus juga menjelaskan tentang bagaimana proses Injil dan dampak Injil bagi jemaat di Korintus. Bahwa "aku telah memproklamasikan Injil kepada kamu

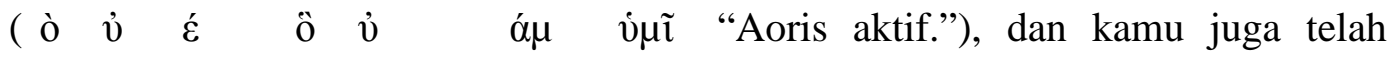

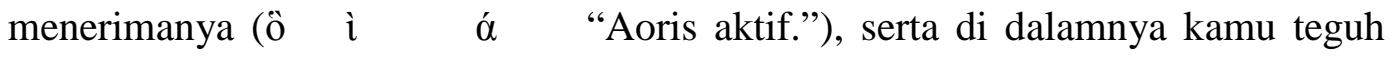

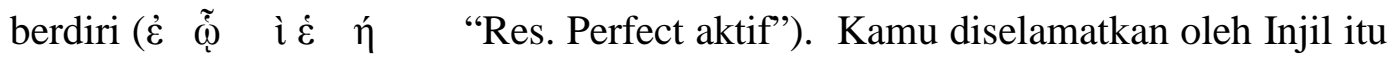

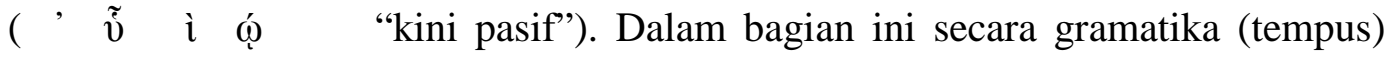
menjelaskan bahwa Paulus sedang mengatakan kepada jemaat di Korintus bahwa mereka telah pernah mendengar tentang Injil dari Paulus dan mereka telah menerima injil itu namun dalam frasa "di dalamnya kamu teguh berdiri" terjadi perubahan tense. Kali ini adalah tense Perfect. Tense Perfect menunjukkan tindakan yang terjadi di sebuah titik waktu, namun itu memiliki hasil yang terus sampai sekarang: "Perfect with s present force-stative verb." ${ }^{\text {43 }}$ Perhatikan apa yang Paulus katakan: “Aku telah memproklamasikan Injil kepada kalian dalam titik waktu, kalian telah menerima dan percaya pada titik waktu, dan kemudian kalian mengambil sikap untuk menerima dan percaya kepada Injil yang sampai saat ini kalian masih berdiri di atasnya sehingga kalian diselamatkan.” Bahwa dari pertama mereka menerima injil sampai sekarang mereka tetap berdiri diatas injil itu. Oleh karena itu mereka sekarang beroleh keselamatan sebagai akibat dari menerima dan tetap berdiri di atas injil itu. Paulus melanjutkan dengan kalimat “jika kamu memegang teguh kepada perkataan yang telah aku proklamasikan kepada mu, kecuali kalau kamu telah sia-sia menjadi percaya.” Frasa tívı $\lambda o ́ \gamma \varphi$

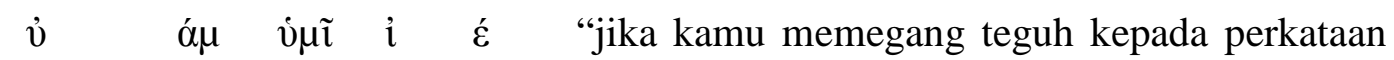

43 Daniel B. Wallace, The Basics of New Testament Syntax: An Intermediate Greek Grammar (Grand Rapids: Zondervan, 2009)., 249. 
yang telah aku proklamasikan kepada mu"adalah menunjuk kepada Injil yang telah disampaikan Paulus (A-A'), Thiselton berpendapat;

That $\lambda$ oyo denotes not simply word, message, or act of speaking but also the content or substance of a declaration, assertion, proposition, or other communicative act. The verb $\varepsilon v \alpha v \gamma \gamma \varepsilon \lambda_{1} \zeta_{0} \alpha_{1}$ already means to proclaim the gospel; hence Paul refers to the substance of the gospel that $i$ proclaimed to you. $^{44}$

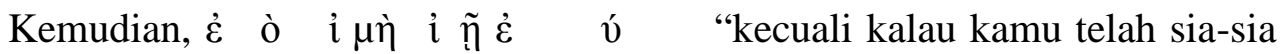
menjadi percaya" merupakan "the counterpoint" terhadap kalimat "serta di dalamnya kamu teguh berdiri, kamu diselamatkan oleh Injil itu” (B-B'). ${ }^{45}$ Paulus pada bagian ini sedang memperingatkan jemaat di Korintus bahwa Injil yang telah dia sampaikan adalah suatu kebenaran bukan suatu kebohongan atau mitos. Namun demikian, Injil yang olehnya orang-orang percaya diselamatkan adalah pesan tentang kuasa dan kekuatan ilahi; ini mengandung janji bahwa mereka yang memandang kepada Kristus di dalam iman kini sedang diselamatkan dan pada akhirnya akan diselamatkan pada hari terakhir-waktu konsumasi. ${ }^{46}$ Satu-satunya cara bagi orang-orang Korintus untuk sia-sia saja menjadi percaya ialah apabila mereka menolak apa yang telah mereka terima di masa lampau. Oleh karena itu Paulus tidak mempertanyakan kebenaran Injil itu sendiri, meskipun memang benar bahwa tanpa kebangkitan Kristus seluruh iman Kristen akan sia-sia (ayat $14,17)$.

Paulus memberikan respons keduanya terhadap kondisi jemaat dengan membaginya menjadi dua tahap narasi penuturan; (i) Paulus menjelaskan tentang isi dan kualitas Injil dari sebelum dan sampai dengan era kebangkitan (3-4); (ii) Paulus menjelaskan tentang isi dan kualitas dari Injil pasca era kebangkitan (5-8).

\footnotetext{
${ }^{44}$ Thiselton, The First Epistle to the Corinthians., 1185.

${ }^{45}$ Fee, The First Epistle to the Corinthians., 801.

${ }^{46}$ Lihat: 1 Kor. 1:18, 21; Rm. 1:16 band. Rm. 5:9, 10; 13:11; 1 Tes. 1:10).
} 
Paulus mulai dengan menututurkan apa yang diketahui dan dipercayai tentang Yesus Kristus. Di antara tradisi-tradisi yang pernah ia sampaikan kepada orangorang Korintus (1Kor. 11:2). Ini merupakan pengakuan iman yang juga telah ia terima sendiri. Di sini ia menggunakan istilah-istilah yang sama untuk meneruskan sebuah tradisi iman seperti yang dilakukannya dalam 1 Korintus 11:23. Kecuali bahwa ia menghilangkan kata-kata "dari Tuhan." Ia telah meneruskan pengakuan iman ini sebagai sesuatu yang urgen. Bahwa pesannya sungguh merupakan dasar bagi seluruh iman Kristen. ${ }^{47}$ Ridderbos mengungkapkan hal yang sama bahwa Paulus sedang berbicara tentang tradisi rasuli yang dia dan para rasul lain letakkan sebagai fondasi seluruh pengajaran

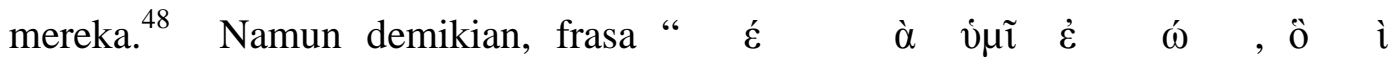
$\pi \alpha \rho \varepsilon ́ \lambda \alpha \beta o v "$ dapat pula berarti bahwa inilah yang pernah pertama-tama ia sampaikan pada awal mula pelayanannya di Korintus dan cara ini mirip dengan suratnya kepada jemaat di Tesalonika (1 Tes. 4:13-18).

Paulus menyatakan bahwa Kristus telah mati karena dosa-dosa kita, ini adalah inti berita Injil dan di dalam surat Paulus yang lebih awal "bahwa Yesus

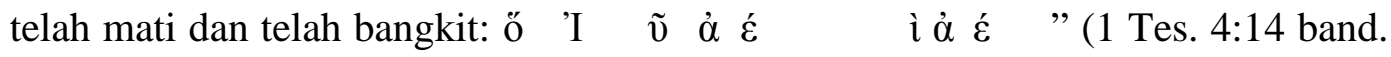
Rm.: 5:6; 2Kor.5;14; Gal.: 1:4). ${ }^{49}$ Kematian-Nya bukan merupakan suatu kebodohan tetapi Yesus "telah diserahkan karena pelanggaran kita" (Rm. 2:25), Ia "telah diserahkan Allah menurut maksud dan rencana-Nya" (Kis. 2:23). Bahwa pengurbanan-Nya adalah sempurna untuk menebus dosa-dosa seluruh umat manusia. Karya ini adalah merupakan konsep dari subtitusi yang dikerjakan oleh

\footnotetext{
${ }^{47}$ Fee, The First Epistle to the Corinthians., 801.

${ }^{48}$ Herman Ridderbos, Paulus Pemikiran Utama Theologianya (Surabaya: Momentum, 2008).

${ }^{49}$ Fee, The First Epistle to the Corinthians., 803.
} 


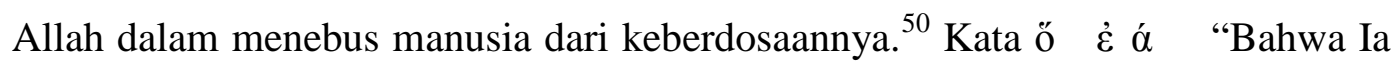
telah dikuburkan" bukan hanya menunjukkan realitas-historis bahwa Yesus telah mati tetapi juga menunjukkan akan realitas-historis akan kebangkitan-Nya. ${ }^{51}$ Kematian Yesus harus menjadi penggenapan dari sebuah rencana ilahi (Lihat: Yes.53) dan hal ini secara sempurna telah digenapi oleh Yesus Kristus di dalam kematian-Nya (1 Ptr. 2:21; Mzm. 118:22; Ul. 21:23). Fee berpendapat bahwa "The gospel is not wisdom humanly conceived but story of a crucified Messiah who die on behalf of sinners." 52

Yesus Kristus adalah hikmat Allah yang berikarnasi, dan orang percaya harus menerima Kristus sebagai hikmat Allah. ${ }^{53}$ Penguburan Kristus itu sendiri tidak mempunyai makna penyelamatan; bahwa Ia telah dikuburkan menegaskan kenyataan tentang kematian-Nya adalah realita objektif-historis bukan hanya secara "spritual" atau "fenomena" semata (sama seperti Daud; Kis. 2:29). ${ }^{54}$ Akibatnya, kebangkitan Kristus sungguh-sungguh berarti bahwa Ia kembali hidup. Bahwa Ia dibangkitkan, pada hari yang ketiga adalah kesaksian dari keempat laporan Injil tentang nubuatan kebangkitan Yesus Kristus. Ini adalah peristiwa unik telah terjadi di masa lalu; Kata kerja $\dot{\varepsilon} \eta^{\prime} \gamma \varepsilon \rho \tau \alpha ı$ (indikatif perfekt pasif: "Ia dibangkitkan" bentuk waktu kata kerja yang digunakann menunjukkan keterangan waktu yang masih berlangsung. bahwa momentum realitas historis objektif tentang kebangkitan Yesus Kristus adalah suatu peristiwa yang mempunyai signifikansi secara kontinyu sampai masa kini dan bahkan masa depan: Kristus

\footnotetext{
${ }^{50}$ Fee, 805.

${ }^{51}$ Thiselton, The First Epistle to the Corinthians., 1992.

${ }^{52}$ Fee, The First Epistle to the Corinthians., 805.

${ }^{53}$ N.T. Wright, God's Plan and Paul's Vision (Downers Grove: IVP Academic, 2009)., 157.

${ }^{54}$ Fee, The First Epistle to the Corinthians, 805.
} 
telah mati, tetapi kini Ia adalah Tuhan yang hidup. ${ }^{55}$ Penekanan ini terdapat di balik keenam penegasan dalam ayat 12-20 terhadap kenyataan bahwa Kristus telah dibangkitkan. Kemudian bentuk pasif menggambarkan suatu cara berbicara berputar mengenai Allah tanpa benar-benar menyebutkan nama-Nya yang kudus (lihat. Rm. 4:24; 6:4; 2 Tim. 2:8). Pada ayat 15 menguraikan makna selengkapnya: Allah membangkitkan Yesus. ${ }^{56}$ Pokok ini sungguh bermakna dan memakai prespektif PL dalam mengungkapkan karya Allah yang besar.

Dalam PL, pengakuan-pengakuan iman yang besar selalu mengakui apa yang Allah telah lakukan untuk umat-Nya di dalam realitas-historis (Ul. 6:20-25; 26:5-11; Yos. 24:2-13). Penekanan yang sama itu pula ditemukan di sini. Bahwa pengakuan tentang Yesus Kristus selalu merupakan pengakuan tentang "perbuatan-perbuatan besar yang dilakukan Allah" (Kis. 2:11, 2224). Dalam konteks 1 Korintus 15 Paulus sedang menuturkan bahwa kebangkitan juga terjadi sesuai dengan Kitab Suci. Yesus telah menubuatkan bukan hanya kematian-Nya tetapi juga kebangkitan-Nya pada hari yang ketiga (Mat. 16:21; Mrk. 8:31 menyebutkan "pada hari ketiga"). Ia juga mengingatkan pembacanya tentang karya penyelamatan TUHAN kepada Yunus setelah berada di perut ikan selama tiga hari dan tiga malam (Lihat; Yun 1:17-2:1 band Mat. 12:40). Kematian, penguburan-Nya dan kebangkitan-Nya adalah sesuai dengan kitab suci dan merupakan suatu penggenapan ilahi melalui kuasa Ilahi untuk menyelamat manusia yang berdosa. ${ }^{57}$ Melalui karya Yesus Kristus inilah kuasa dan kasih karunia Allah menjadi nyata dan bekerja di dalam diri para rasul dan orang percaya.

\footnotetext{
${ }^{55}$ Fee.805.

${ }^{56}$ Lihat: 1 Kor. 6:14; Rm. 4:24; 8:11; 10:9; 2 Kor. 4:14; Gal. 1:1; Ef. 1:20; Kol. 2:12.

${ }^{57}$ Thiselton, The First Epistle to the Corinthians, 1195.
} 
Yesus Kristus yang telah bangkit, menampakkan diri kepada Kefas (band. 1 Kor. 1:2; Luk. 24:34; Gal. 2:7, 8). Petrus dalam surat Paulus selalu disebut Kefas. Statusnya yang khusus dalam jemaat mula-mula barangkali berasal dari penampakan yang khusus ini, maupun pada kedudukannya yang istimewa di dalam lingkungan para murid semasa pelayanan Yesus. Barangkali juga di sini Paulus dengan sengaja mengikutsertakan bagian dari tradisi yang dikutipnya ini, ${ }^{58}$ karena Petrus sangat dikenal di Korintus, dan pernah mempunyai pendukungnya yang khusus pula (1 Kor. $1: 12 ; 3: 22 ; 9: 5)$. Kata $̋ \varphi \theta \eta$ (Indikatif aoris aktif), Paulus sedang menekankan bahwa kebangkitan Yesus Kristus adalah suatu realitas historis objektif dalam suatu eksistensi "tubuh" dan bukan dalam bentuk eksistensi "spiritual" ${ }^{59}$ Inilah satu-satunya tempat di mana Paulus menyebutkan kedua belas murid Yesus. Sejak Yudas Iskariot meninggal, mungkin hanya 11 orang yang disebutkan dalam Matius 28:16, 17 dan Lukas 24:33. Meskipun mungkin lebih banyak lagi yang sungguh-sungguh hadir menurut Injil Lukas. Namun keseluruhan dari kedua belas murid yang hadir pada penampakan dicatat dalam Yohanes 20:19-29 dan 21:2-14. ${ }^{60}$ Jumlah dua belas itu sudah formal untuk menyebut kesaksian para rasul yang telah mengikuti Yesus dari sejak Dia hidup dan terus menjadi saksi peristiwa penyaliban Yesus Kristus dan kebangkitan-Nya. ${ }^{61}$ Seperti frasa "Ia telah dibangkitkan" (ayat 4), Ia menampakkan diri dalam bahasa Yunani menggunakan sebuah kata kerja pasif dengan makna tersirat yang aktif; secara harfiah kata ini berarti "Ia dilihat", tetapi implikasinya ialah: Allah memperlihatkan-Nya. Konsekuensinya, bahkan

\footnotetext{
${ }^{58}$ Fee, The First Epistle to the Corinthians., 808.

${ }^{59}$ Fee, 808.

${ }^{60}$ Fee dan Stuart, How to Read the Bible Book By Book: a Guided Tour., 809

${ }^{61}$ Thiselton, The First Epistle to the Corinthians., 1205
} 
penampakan-penampakan kebangkitan itu diakui sebagai bagian dari karya Allah yang besar dan dengan demikian membuktikan bahwa sengat maut telah ditiadakan oleh-Nya (1Kor:15: 55).

Paulus mencatat kesaksian-kesaksian lain. Tidak pernah ada laporan bahwa Ia menampakkan diri kepada lebih dari lima ratus saudara sekaligus. Paulus menuturkan ini dengan tujuan sebagai penegasan dari peristiwa kebangkitan Yesus Kristus. ${ }^{62}$ Bahwa jemaat di Korintus yang ingin membuktikannya, mereka dapat memeriksa fakta-faktanya dari para saksi-saksi yang masih hidup.

Yesus Kristus menampakkan diri kepada Yakobus juga tidak dicatat di tempat-tempat lain. Peranannya yang khusus sebagai pemimpin jemaat di Yerusalem (Kis. 12:17; 15:13-21; Gal. 1:9) barangkali dapat ditelusuri kembali pada peristiwa ini, walaupun pada kenyataan bahwa ia juga adalah saudara Tuhan Yesus Kristus. Pada akhirnya, Yesus Kristus menampakkan diri kepada semua rasul, kepada semua saksi perdana yang di Yerusalem. Tujuan dari semua ini adalah untuk menegaskan akan kualitas kebangkitan Kristus adalah benar-benar sahih. Kebangkitan Kristus adalah realitas historis yang objektif dengan adanya banyak saksi kebangkitan Yesus Kristus. ${ }^{63}$ Kini Paulus tiba pada diri sendirnya sebagai saksi kebangkitan Yesus Kristus. Ia muncul yang paling akhir dari semuanya. Ini bukanlah suatu tanda kerendahan hati yang palsu, tetapi dia sedang menekankan, pada kenyataannya: "Kristus menampakkan diri juga kepadaku, sehingga aku berhak untuk disebut sebagai rasul" (1 Kor. 1:1; 9:1). Ia menggunakan kata kerja yang sama untuk penampakan ini di jalan menuju

\footnotetext{
${ }^{62}$ Fee, The First Epistle to the Corinthians., 809

${ }^{63}$ Fee, 809.
} 
Damsyik, seperti yang dipergunakannya untuk penampakan-penampakan lainnya (Kis. 9:17; 26:16). ${ }^{64}$ Kedudukannya sebagai rasul sama sekali tidaklah lebih rendah dari pada kedudukan yang lainnya, bahkan kalaupun Yesus Kristus menampakkan diri-Nya belakangan kepadanya dan dengan cara yang unik: sama

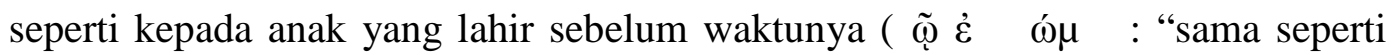
kepada anak yang lahir sebelum waktunya." Paulus diduga sedang mengangkat sebuah istilah penghinaan yang dilontarkan padanya oleh lawan-lawannya di Korintus. Kata Yunani yang diterjemahkan dengan sama seperti kepada anak yang lahir sebelum waktunya berarti kepada janin dari seorang ibu yang hamil tetapi mengalami keguguran. Terminologi ini juga digunakan untuk menggambarkan monster yang buruk rupa atau mengerikan. Bahkan nama Yunani Paulos. Nama ini berarti "orang pendek/kecil." (band. 2 Kor.10:10). ${ }^{65}$ Akan tetapi berdasarkan konteks terdapat kecenderungan bahwa Paulus sedang membadingkan realitas hidupnya sekarang sebagai rasul Yesus Kristus dengan sebelum menjadi seorang rasul. Ia dulu adalah penganiaya para pengikut Yesus Kristus tetapi jika sekarang telah menjadi orang percaya dan itu adalah kasih kerunia semata.

Paulus mengatakannya sendiri bahwa ia layak mendapatkan tempat yang paling bawah karena ia adalah yang paling hina karena ia telah menganiaya Jemaat Allah (Kis. 8:3; 9:1; 22:4; 26:9-11). TUHAN mentransformasi sang penganiaya menjadi seorang misionaris yang besar (Gal. 1:13-16). Transformasi yang sepektakuler adalah kasih karunia semata dan untuk memenuhi tujuan TUHAN melalui hidupnya (Ef. 3:8; band. 1 Tim. 1:15, 16; Rm. 1:5; 1Kor.3:10).

\footnotetext{
64 Fee, 809.

${ }^{65}$ Fee, 809.
} 
Pada akhir penuturannya rasul Paulus menekankan bahwa tidak menjadi masalah siapa yang memberitakan Injil, apakah dirinya atau para rasul dan misionaris lainnya (baik aku, maupun mereka). Mengapa? Karena masing-masing orang hanyalah seorang hamba yang menunaikan tugas yang ditetapkan TUHAN untuk kekerjakan dengan setia (1 Kor. 3:5-10 band. Ibr. 1:4). ${ }^{66}$

Berdasarkan penuturan interpretasi di atas dapat ditarik kesimpulan bahwa 1 Korintus 15: 1- 11 adalah bagian pertama dari keseluruhan pasal 15. Dalam bagian ini Paulus sedang mengingatkan kepada jemaat di Korintus akan adanya keraguan tentang kebangkitan orang mati (ay. 12). Kebangkitan Yesus Kristus adalah dasar pengharapan dan iman tentang kebangkitan orang percaya. Kebangkitan Yesus Kristus adalah satu realitas-historis objektif. ${ }^{67}$ Paulus berfokus kepada karya Yesus Kristus, dan pemberian Roh Kudus. Kebangkitan Yesus Kristus menandakan era baru dan pemberian Roh Kudus adalah bukti bahwa zaman akhir telah mulai. Tetapi tubuh kita adalah tubuh yang fana (Ibr. 15:49-53) dan Yesus Kristus belum datang (Ibr. 11:26; 15:23) serta kebangkitan orang mati masih akan menyusul (Ibr. 15:20-28). Oleh karena itu keselamatan orang percaya belum sempurna dan lengkap. Bagi Paulus, orang Kristen adalah orang yang ditentukan oleh realitas masa depan yang sudah mulai, tetapi yang masih menantikan kemuliaan terakhir (Konsumasi).

\section{Signifikansi Terhadap Ajaran Bultmann Dan Tradisi "Rambu Solo"}

Konsep kebangkitan orang mati merupakan ide dan gagasan yang telah dimiliki berbagai kepercayaan nenek moyang sejak ribuan tahun yang lampau. Terlepas dari seberapa kuat pemahaman-pemahaman tersebut berhadapan dengan

\footnotetext{
${ }^{66}$ Fee, 803.

${ }^{67}$ Bracken, "Incarnation, panentheism, and bodily resurrection: A systems-oriented approach."77.
} 
ajaran dari agama-agama tertentu sehingga terjadi sinkritisme, namun dapat dipastikan bahwa usia konsep kebangkitan orang mati sama tuanya dengan peradaban manusia di dunia. Kondisi inilah yang mempengarui Bultmann sehingga berpendapat bahwa kebangkitan Yesus Kristus adalah mitologis semata dan historis. ${ }^{68}$ Di Indonesia dengan keberagaman pemahaman suku-suku yang ada memandang kehidupan setelah kematian sebagai eksistensi manusia yang nyata. Bagi orang Toraja roh orang mati yang telah berada di Puya mampu memberi berkat. Sebelum roh orang mati menuju tempat peristirahatan terakhir akan dilaksanakan upacara yang disebut Rambu Solo.

Melalui ritual tersebut keluarga mempersiapkan berbagai ritual untuk jenazah yang dipahami masih memiliki eksistensi dengan dunia, Rambu Solo diartikan juga sebagai bentuk memberikan persembahan kepada orang mati. ${ }^{69}$ Orang Toraja yang meninggal, selama belum dilakukan upacara Rambu Solo lingkungan sosial menganggapnya masih berada di dalam komunitasnya. ${ }^{70}$ Biasanya keluarga yang berduka selalu meletakkan sesajian berupa makanan dan minuman, bahkan setelah selesai dikubur. Ada yang mengkritisi dan ada yang menganggapnya biasa sebagai budaya yang tidak berkaitan dengan iman percaya. Kebangkitan orang mati dalam tradisi agama nene moyang (aluk todolo) berbeda dengan ajaran Paulus dalam Alkitab. Orang Toraja melihat kesinambungan hidup di dunia dan dunia orangmati dalam gambaran semu yang biasa dipahami kebanyakan dari ajaran agama-agama suku lainnya. Jelas bahwa, sebagian orang 17.

${ }^{68}$ Rudolf Bultmann, Jesus Christ an Mythology (New York: Charles Schribner's Sons, 1958)., 14-

${ }^{69}$ Frans Pantan, UPACARA RAMBU SOLO'Suatu Studi Kritis Teologis Terhadap Upacara Rambu Solo' Pada Masyarakat TorajaKristen (Jakarta: DEPARTEMEN TEOLOGI SINODE GEREJA BETHEL INDONESIA, 2018), 6-8.

${ }^{70}$ Tony Salurante, Ku Antar Kau Menuju Surga dengan Tedong: Kontribusi Pemikiran Orthodoks Agustinus dan Hoekema terhadap Pandangan yang keliru dari Konsep kematian di Tana Toraja (Jakarta: DELIMA, 2016), 18. 
Toraja masih mempercayai akan hal tersebut dalam ekspresi yang lain yang tidak lagi sama seperti leluhur mereka. Dimana kurban pemotongan kerbau dilakukan hanya sekedar ekspresi kebersamaan dan tanggungjawab moril dari seluruh rumpun keluarga. Akan tetapi leluhur orang Toraja melihat pengorbanan hewan pada upacara Rambu Solo sebagai kendaraan yang akan membawa kepada suatu kehidupan menuju tempat yang dipahami, yaitu Puya.

Kebangkitan dalam ajaran Kristen adalah sebuah kepastian yang menjadi harapan orang percaya dalam Kristus. Sebagian orang Toraja adalah orang Kristen yang percaya kepada Kristus yang telah mati dan bangkit. Sikap kesukuaan yang ditunjukkan sebagian besar orang percaya di Toraja jika tidak diimani dengan pengorbanan Kristus bisa mencemari kemurnian iman. Pemahaman yang benar tidak menyebabkan orang percaya terjebak di satu ekstrem namun mampu memaknai kebudayaan manusia dalam terang Injil dengan tepat. Jika orang Toraja masih melakukan Rambu Solo sebagai bentuk ekspresi sukacita karena kematian manusia yang membawa kehidupan kekal maka melaksanakan "pesta budaya" tersebut adalah baik. Tetapi jika melaksanakan ritual tersebut mengandung paham-paham yang bertentangan dengan iman Kristen dan memelihara ritual budaya leluhur akan berpengaruh kepada pertumbuhan iman gereja. Jelas ini adalah sebuah proses penilaian yang harus benar-benar komprehensif. Tidak tuntas dalam menilai, sebagaimana dikatakan Pantan bahwa: "Tata cara dan pemahaman tradisi Aluk Todolo pada upacara Rambu Solo' harus diganti dengan tata cara dan pemahaman iman Kristen berdasarkan Alkitab."71 Pantan belum jelas memberikan solusi bagaimana orang Toraja harus menggantinya, sekalipun ia

\footnotetext{
${ }^{71}$ Pantan, Upacara Rambu Solo'Suatu Studi Kritis Teologis Terhadap Upacara Rambu Solo' Pada Masyarakat TorajaKristen., 6-8.
} 
melihat ada nilai-nilai positif yang terkandung dalam upcara tersebut. Ritual Rambu Solo bisa menjadi jembatan bagi orang Kristen memahami dengan jelas tentang kebangkitan Kristus, baik yang mampu melaksanakan maupun tidak karena mereka berada dalam komunitas iman yang bisa saling mempengaruhi. ${ }^{72}$

\section{KESIMPULAN}

Berdasarkan eksegesis 1Korintus 15: 1-11 menghasilkan beberapa kesimpulan dan signifikansi. Pertama kesimpulan: (i) kebangkitan Yesus Kristus adalah suatu realitas historis objektif dan buka fenomena dan hanya secara spiritual semata; (ii) Ajaran tentang kebangkitan Yesus Kristus adalah merupakan isi dari Injil yang disampaikan oleh Paulus dan para rasul yang lain serta menjadi fondasi iman yang kokoh bagi orang percaya; (iii) Kebangkitan Yesus Kristus juga menjadi jaminan bagi adanya kebangkitan orang mati disamping itu ajaran tentang kebangkitan Yesus Kristus adalah merupakan bagian fudamental dari teologi Paulus. Ada dua signifikansi yang bermanfaat bagi orang percaya yaitu teologis dan praktis. Pertama, teologis. Bahwa realitas hitoris objektif dari kebangkitan Yesus kristus adalah merupakan jaminan yang kokoh dari Allah tentang akan adanya kebangkitan orang mati di era yang akan datang dan yang telah ditentukan oleh Allah sendiri. Oleh karena itu pokok pengajaran ini menjadi pengharapan bagi orang percaya. Kedua, praktis. Kebangkitan Yesus Kristus bermanfaat untuk menjadi penerang atau petunjuk dalam menjalani realitas kehidupan. Bahwa secara praktis orang percaya harus menolak ajaran Bultmann tentang kebangkitan dan prinsip-prinsip upacara kematian "Rambu Solo" yang

\footnotetext{
72 Tony Salurante, "Ritual Slaughtering of Livestock in 'Aluk Rambu Solo': How the way of Torajan Appropriate the Doctrine of Jesus as Sacrifice," Diegesis Vol.5 No.2 (2020): 64-77, https://doi.org/10.46933/DGS.vol5i264-77.
} 
tidak Alkitabiah. Budaya "Rambu Solo" tidak perlu dihilangkan akan tetapi diterangi dengan kebenaran Firman TUHAN sehingga mengalami transformasi dalam pemahaman yang baru.

\section{DAFTAR PUSTAKA}

Archibald, Robertson, dan Alferd Plummer, ed. A Critical and Exegetical on the first Epistle of ST Paul to the Corinthians. International Critical Commentary. Edinburgh: T. \& T. Clark, 1914.

Bailey, James L. "Genre Analysis." Dalam Hearing the New Testament:Srategies for Interpretation. Grand Rapids: Eerdmans, t.t.

Bock, Darrell L., dan Daniel B. Wallace. Mendongkel Yesus dari TahtaNya:Upaya Mutakir untuk Menjungkir-Balikkan Iman Gereja Mengenai Yesus Kristus. Jakarta: Gramedia, 2009.

Bracken, Joseph A. "Incarnation, panentheism, and bodily resurrection: A systems-oriented approach." Theological Studies 77, no. 1 (2016): 32-47. https://doi.org/10.1177/0040563915619977.

Bray, Gerald. 1-2 Corinthians. Ancient Christian Commentary on Scripture New Testament VII. Disunting oleh Gerald . Bray. Downers Grove: InterVarsity, 1999.

Bultmann, Rudolf. Jesus Christ an Mythology. New York: Charles Schribner's Sons, 1958.

Carson, D.A., dan Moo Douglas J. An Introduction To The New Testament. Grand Rapids: Zondervan, 1992.

Ciampa, Roy E., dan Brian S. Rosner. The First Letter to the Corinthians. England: Apollos, 2010.

Ehrman, Bart D. "Textual Criticism of the New Testament." Dalam Hearing the New Testament:Srategies for Interpretation, disunting oleh Joel B. Green. Grand Rapids: Eerdmans, 2010.

Fee, Gordon D. Exegese van het Nieuwe Testament: een praktische handleiding. Zoetermeer: Boekencentrum, 2007.

—. The First Epistle to the Corinthians. Grand Rapids: Eerdmans, 2014.

Fee, Gordon D., dan Douglas. Stuart. How to Read the Bible Book By Book: a Guided Tour. Grand Rapids: Zondervan, 2002. 
Garland, David E. 1 Corinthians. Grand Rapids: Baker Academic, 2003.

Geisler, Norman L. Miracles and the Modern Mind. Grand Rapids: Bakerbook House, 1991.

Hawthorne, Gerald F., Ralph P. Martin, dan Daniel G. Reid, ed. Dictionary of Paul and His Letters. Downers Grove: IVP Academic, 1993.

Kistemaker, Simon J. First Epistle to the Corinthians. Grand Rapids: Baker Academic, 1993.

Klein, William W., Craig L. Blomberg, dan Jr. Hubbard, Robert L. Introduction to Biblical Interpretation. Dallas: Thomas Nelson, 2004.

Metzger, Bruce M. A Textual Commentary on The Greek New Testament. New York: American Bible Society, 2002.

Murre, Johan. Lexicon: Nieuwe Testament. The Nederlands: Skandalon, 2009.

Norman, David J. "Doubt and the Resurrection of Jesus." Theological Studies 69, no. 4 (2008): 786-811. https://doi.org/10.1177/004056390806900402.

Pantan, Frans. Upacara Rambu Solo'Suatu Studi Kritis Teologis Terhadap Upacara Rambu Solo' Pada Masyarakat TorajaKristen. Jakarta: Departemen Teologi Sinode Gereja Bethel Indonesia, 2018.

Porter, Stanley E., dan Kent D. Clarke. "What Is Exegesis? An Analysis of Various Definitions." Dalam Handbook to the exegesis of the New Testament, disunting oleh Stanley E. Porter, 3-21. Leiden: BRILL, 1997.

Ridderbos, Herman. Paulus Pemikiran Utama Theologianya. Surabaya: Momentum, 2008.

Salurante, Tony. Ku Antar Kau Menuju Surga dengan Tedong: Kontribusi Pemikiran Orthodoks Agustinus dan Hoekema terhadap Pandangan yang keliru dari Konsep kematian di Tana Toraja. Jakarta: DELIMA, 2016.

—. "Ritual Slaughtering of Livestock in 'Aluk Rambu Solo': How the way of Torajan Appropriate the Doctrine of Jesus as Sacrifice." Diegesis Vol.5 No.2 (2020): 64-77. https://doi.org/10.46933/DGS.vol5i264-77.

Smith, Kevin Gary. Writing and Risearch: A Guide for Theological Student. UK: Langham Global Library, 2016.

Thiselton, Antony C. The First Epistle to the Corinthians. Grand Rapids: Eerdmans, 2000.

Wallace, Daniel B. The Basics of New Testament Syntax: An Intermediate Greek Grammar. Grand Rapids: Zondervan, 2009. 
Witherington III, Ben. Conflict \& Community in Corinth: A Sosio-Rhetorical Commentary on 1 and 2 Corinthians. Grand Rapids: Eerdmans, 1995.

Wright, N.T. God's Plan and Paul's Vision. Downers Grove: IVP Academic, 2009. 